\title{
ANTIOXIDANT ACTIVITY TEST OF THE RED YEAST RICE EXTRACT AND THE FORMULATION IN A CREAM PREPARATIONS ANDIT'S PENETRATION AND SAFETY TEST AT RABBIT
}

\author{
Jason Merari Peranginangin, Muhammad Dzakwan, Hadrah Arisca \\ Fakultas Farmasi, Universitas Setia Budi \\ Jl. Letjend Sutoyo, Mojosongo, Surakarta 57127 \\ Corresponding author : jason.merari@yahoo.com
}

\begin{abstract}
Red yeast rice is one of thefoodstuff that contains flavonoid compounds which are useful as natural antioxidants. One attempt to overcome wrinkles is with antioxidants. The easy way to apply red yeast rice can be make in an extract that are formulated in cream preparations.

This study aims to determine the antioxidant activities of Red yeast rice extract and its formulation in cream dosage form and the test of penetration and safety. Red yeast rice extract obtained by the method of maseration using ethanol $96 \%$ as a solvent. The cream is make in 3 formula, where the first formula as a negative control, second formula is cream of red yeast rice extract and third formula is cream of red yeast ricemicroemulsion. The antioxidant activity tested by DPPH method, the penetrationstrengthtested by Franz difussionmethod and the safety by primary and ocular irritation test. Research results demonstrated that red yeast rice extract had activity as antioxidant with the $\mathrm{IC}_{50}$ value was $2,60 \mathrm{ppm}<50 \mathrm{ppm}$ (strong antioxidant) and microemulsion cream had penetrationstrength greater than red yeast rice extractcream. And the results of the primary irritation test showed that the cream is very little irritate and the results of the ocular irritation test cream does not irritate the eyes.
\end{abstract}

Keywords : red yeast rice extract, antioxidant activity, cream, penetration, safety tes

\section{Introduction}

Antioxidants are compounds that can inhibit oxidation reactions caused by free radicals. Antioxidants will react with reactive free radicals to form free radicals that are not reactive and are relatively stable by donating hydrogen or electron atoms (Pratimasari 2009). Antioxidants are important substances needed by the body to protect from free radical attacks and reduce the negative effects of free radicals (Zuhra et al. 2008). Antioxidants can be divided into two groups, namely antioxidants in the form of enzymes and non-enzymes. Antioxidants in the form of enzymes in the body such as glutathione peroxidase, superoxide dismutase, and catalase. Non-enzyme antioxidants come from fruits, vegetables, and the isolation of natural ingredients such as vitamin A, vitamin C, vitamin E, beta-carotene, and flavonoids (Shahidi \& Ambigaipalan 2015). One of the natural ingredients that are thought to have high antioxidant content is red yeast rice.

Red yeast rice is one of the rice fermentation products using Monascus purpureus which goes through a solid phase process. Grains of rice that were white will be covered with red pigment produced during fermentation. The red color has the potential as a substitute for synthetic red color and as a source of natural antioxidants.Monascus purpureus which is grown on rice as a substrate can produce yellow, red and orange pigments. Pigments produced by red yeast rice contain anthocyanin substances from flavonoids which have strong (Wanti 2008). Red yeast rice is traditionally produced using rice substrates. In general, red 
yeast rice circulating in the market are in the form of whole rice (Jenie et al. 1994).

The antioxidant content of red yeast rice can inhibit premature aging. Aging is a process that occurs in all living tissues, but the most visible is on the skin. The factors that cause skin aging are intrinsic and extrinsic factors. The intrinsic factor that causes premature aging is an increase in free radicals and DNA damage. Extrinsic factors that influence the occurrence of premature aging are UV rays and smoking (Dewiastuti \& Hasanah 2016).

In preventing premature aging, many cosmetic products are used. Cosmetic products generally have an ordinary delivery system application, to make the delivery system easier and faster to absorb, it can be made in the form of microemulsion-based creams. Cream is a semi-solid preparation containing one or more dissolved or dispersed medicinal ingredients in the appropriate base material (Anonim 2014). The advantage of cream is to have a fairly high aesthetic value and a good level of comfort in use. In addition, cream preparations are preparations that are easy to wash, are nonsticky, have an effect on moisturizing the skin and have good spread ability.

Microemulsion is a thermodynamically stable and transparent system, which is a dispersion of oil and water which is stabilized by surfactants and cosurfactants (Talegaonkar et al. 2008). Microemulsion causes drug delivery to be better than conventional emulsions because it can increase the solubility of drugs that are difficult to dissolve in water because of their smaller particle size (Shalviri et al. 2011). In general, microemulsions are composed of oil phases, water phases, surfactants and cosurfactants (Dizaj 2013). Studies show that types of fatty acids or components in the oil phase can affect the stability of microemulsions.

To ensure the use of red yeast rice extract, antioxidant activity was tested by using DPPH method and its application was in the form of cream preparations, then testing the penetration power in vitro with Franz diffusion method and safety test in vivo (primary and ocular irritation test).

\section{Methods}

\section{Materials}

The material used is red yeast rice. The solvent used for maceration is $96 \%$ ethanol. The materials for making cream are cetosteril alcohol, stearic acid, cetyl alcohol, nipagin, nipasol, tween
80, and aqua demineralisata. Cream microemulsion ingredients are soybean oil, virgin oil, olive oil, oleic acid, isopropyl myristate (IPM), 80 Tween ${ }^{\circledR}, 96 \%$ ethanol, aqua pro injection and red yeast rice extract. DPPH, vitamin $\mathrm{C}$ and ethanol p.a are used as controls.

Equipment

The equipment used was oven, milling machine and No. 40 sieve, Mouisture Balance, glass (pyrex), flannel, and evaporator (Heidolp WB 4000), UV-Vis spectrophotometer, and Franz diffusion test equipment, rabbit cage, analytical balance.

\section{Extract preparation}

Ethanol extract was made using maceration method with $96 \%$ ethanol. Maserate obtained is then collected and concentrated with a vaccum rotary evaporator at a maximum temperature of $50^{\circ} \mathrm{C}$ until a thick extract is obtained.

\section{Test animals}

The test animals used in this study were male rabbits (New Zealand strain). Weight 2.5-4 $\mathrm{kg}$, healthy, and no edema or erythema on the back of the skin and no irritation to the eyes

\section{Antioxidant test}

Analysis of antioxidant activity was carried out by DPPH method with a solution of 100 ppm DPPH in ethanol solvent made by weighing $10 \mathrm{mg}$ of DPPH powder inserted in a $100 \mathrm{ml}$ measuring flask then ethanol was added to the boundary markers. The absorbance test of DPPH free radical reduction was carried out on ethanol extract of red yeast rice with various concentrations in $2 \mathrm{ml}$ of ethanol, $2 \mathrm{ml}$ of $\mathrm{DPPH}$ solution was added and absorbance was measured using UV-Vis spectrophotometer at wavelength and operating time to be determined.This test was carried out 3 times using ethanol as blank. And testing was also carried out on vitamin $\mathrm{C}$ which was used as a control comparison.

Table 1. Microemulsion formula of red yeast rice cream(Agustina 2014)

\begin{tabular}{clc}
\hline & \multicolumn{1}{c}{ Material } & Formula $(\mathrm{ml})$ \\
\hline \multirow{4}{*}{ Oil } & Surfactant+ co surfactant & 10 \\
& Virgin Coconut Oil & 1 \\
phase & Isopropil Maristat & 1 \\
& Olive oil & 1 \\
& Oleic acid & 1 \\
Water & Red yeast rice extract 5\% & 1 \\
phase & Aqua demineralized & 1 \\
\hline
\end{tabular}


Table 2. Formula of red yeast rice cream (Bernatoniene et al. 2011., Gaikwad 2011)

\begin{tabular}{ccc}
\hline \multicolumn{2}{c}{ Material } & $\begin{array}{c}\text { Formula } \\
(\mathbf{0})\end{array}$ \\
\hline Oil phase & $\begin{array}{c}\text { Cetostearil } \\
\text { alcohol }\end{array}$ & 7 \\
& Stearic acid & 7 \\
& Cetyl alcohol & 6 \\
Water & Nipasol & 0.05 \\
phase & Nipagin & 0.15 \\
& Tween 80 & 0.5 \\
& $\begin{array}{c}\text { Red yeast rice } \\
\text { Microemulsion }\end{array}$ & 5 \\
& Water & 74.3 \\
\hline
\end{tabular}

Microemulsions making and cream
preparations

Making emulsions using surfactant Tween 80 with glycerin cosurfactant. Optimization is done by changing the concentration ratio of surfactants and cosurfactants. Then the formula that produces emulsions is observed. Emulsion preparation begins with mixing Tween 80 and glycerin cosurfactant, then stirring until dissolved. After that the oil phase is added which is a mixture of virgin oil, olive oil, soybean oil, oleic acid, IPM, and 5\% red yeast rice extract then stirred using a stirer. Then into the mixture water is added little by little with stirring over the stirrer until an emulsion is formed. Cream making must be hot. Stamper and mortar are heated on a water bath. Then making cream using cetosteril alcohol, cetyl alcohol and stearic acid plus nipasol is melted on a water bath (oil phase). In addition it is melted on a nipagin and tween 80 (water phase) at water bath. Enter the oil phase and the water phase into the hot mortar is ground to homogeneous. Then the microemulsion emulsion and aquadest were added gradually crushed to form a cream mass.

\section{Penetrating power test of the Franz diffusion method}

The membrane used is the skin of the abdomen part of the rat aged 2-3 months with a weight of $\pm 180-200$ g. First, the rats were sacrificed then the rats' hairs on the abdominal part were carefully shaved with a razor. After that, the rats' skin was sliced on the abdomen with a thickness of $0.6 \pm 0.1 \mathrm{~mm}$ and the fats in the attached subcutaneous portion were carefully removed. Then the mouse skin was soaked in the medium to be used (phosphate buffer $\mathrm{pH} \mathrm{pH}$ 7.4) for 30 minutes after it was stored at $4^{\circ} \mathrm{C}$. The skin can be used for a span of 24 hours. The receptor compartment is filled with a $\mathrm{pH} 7.4$ phosphate buffer solution of about $13 \mathrm{~mL}$ which is maintained at a temperature of about $37 \pm 0.5^{\circ} \mathrm{C}$ and stirred at a speed of $250 \mathrm{rpm}$. Mouse abdominal skin is then placed between the donor compartment and receptor compartment with the horn layer facing up. A sample of 0.5 grams was applied to the surface of the skin. Then the samples were taken at $30 \mathrm{~m}, 60,90$ and 120 minutes as much as 3 $\mathrm{mL}$ from the receptor compartment using syringe and immediately replaced with a phosphate buffer buffer $\mathrm{pH} 7.4$ of the same volume. Mouse abdominal skin is then placed between the donor compartment and receptor compartment with the horn layer facing up. A sample of 0.5 grams was applied to the surface of the skin. Then the samples were taken at 30 $\mathrm{m}, 60,90$ and 120 minutes as much as $3 \mathrm{~mL}$ from the receptor compartment using syringe and immediately replaced with a phosphate buffer buffer $\mathrm{pH} 7.4$ of the same volume. The samples were measured at the maximum wavelength of red yeast rice extract by UV-Vis spectrophotometer. The reading is done three times.

\section{Safety test}

The irritation test was carried out in vivo in four rabbits using the Draize method. The rabbit used was male (New Zealand) rabbit which had sheared hair on its back. This shaving is done 24 hours before being treated. The test material is given by applying it to the test area. After applying the test material, the test area is then covered with a non-reactive bandage. After 24 hours, the bandage is opened and the test area is cleaned with water to remove the remaining test material.At 24, 48 and 72 hours after administration of the test material, the test area is examined and changes are observed as a skin reaction to the test material and assessed by giving a score of 0 to 4 depending on the severity of the skin reaction seen (Draize 1959).

\section{Statistical analysis}

The antioxidant data obtained were statistically analyzed using Kolmogorof-Smirnov to test the normality of the data and test the independent $\mathrm{T}$-test to see $\mathrm{IC}_{50}$ differences between samples of red yeast rice extract and Vitamin C. The penetration test data obtained were statistically analyzed using KolmogorofSmirnov to test data normality and repeated ANOVA to see differences in penetration between red yeast rice extract cream and microemulsion cream. 


\section{Results and Discussion}

\section{The result of extract making}

The yield of red yeast rice extract obtained was $14.02 \%$

\section{The results of Antioxidant test}

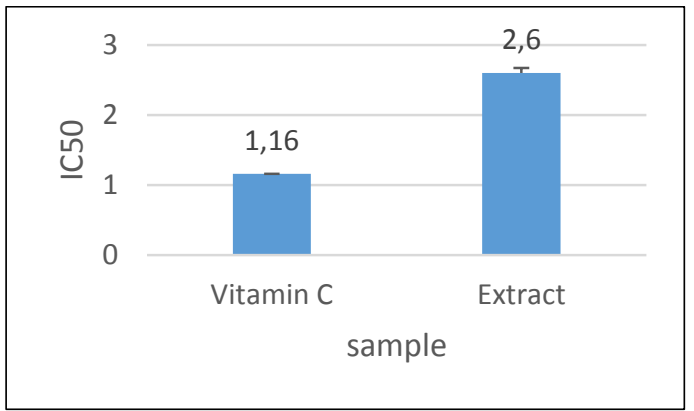

Figure $1 . \mathrm{IC}_{50}$ of vitamin $\mathrm{C}$ and red yeast rice extract

The results of antioxidant activity test obtained $\mathrm{IC}_{50}$ Vitamin $\mathrm{C}$ is $1.16 \pm 0.00 \mathrm{ppm}$ and red yeast rice extract is $2.6 \pm 0.07 \mathrm{ppm}$. A substance has very strong antioxidant properties if the $\mathrm{IC}_{50}$ value is less than $50 \mathrm{ppm}$ (Molyneux 2004). Red yeast rice extract showed $I_{50} 2.60$ ppm $<50$ ppm which indicates that extract has a strong activity as an antioxidant. The strong antioxidant of red yeast rice extract because it contains flavonoid compounds and vitamins (Chairote et al. 2009). Flavonoids in red yeast rice are anthocyanins which are red pigments that have strong antioxidant activity. The strength of antioxidants because of the presence of aleurons and endospermia producing high intensity anthocyanins. Because of the high anthocyanin levels, the antioxidant activity is high too.

When DPPH is added to the red yeast rice extract, purple changes to yellow. Color changes in DPPH due to the presence of free radicals neutralized by the compounds in the extract. The compound that reacts as a radical catcher will reduce DPPH to form a reduced DPPH-H. This reaction was observed in the presence of DPPH color changes from purple to yellow when negative electrons from DPPH radicals had paired with hydrogen from free radical capture compounds (Molyneux 2004). The higher the extract level, the lower the absorbance, which indicates that the greater the antioxidant potential in the extract.
The results of Microemulsion physical stability test

Table 3. Observation of particle size and PDI values of microemulsions

\begin{tabular}{ccc}
\hline Microemulsions & $\begin{array}{c}\text { Particle size } \\
(\mathrm{nm}) \pm \mathrm{SD}\end{array}$ & PDI \pm SD \\
\hline $1: 1$ & $95,063 \pm 0,744$ & $0,377 \pm 0,007$ \\
$1: 2$ & $123,667 \pm 2,103$ & $0,387 \pm 0,006$ \\
$1: 3$ & $152,267 \pm 2,318$ & $0,217 \pm 0,005$ \\
\hline
\end{tabular}

Keterangan : PDI (polidispers index)

Table 3 shows that all formulas have particle sizes within the microemulsion range of 10-200 nm (Grampurohit et al. 2011). To determine the selected formula, it can be seen from the smallest PDI value, that is formula 1:3. Because in determining the selected formula, it is not only seen from the smallest size, in the particle size measurement of particle size microemulsion particle size that is read is not only the size of the extract particles but there are particles particles from the phase of the surfactants and the oil phase that are read are readable which can affect the results, therefore it is seen that the PDI value illustrates the uniformity of particle size weight in a formula. If the PDI value is low then all particle sizes in the 3 phases of the microemulsion formula have the same uniform size. Formula 1: 1 and 1: 2 have a high PDI value compared to 1: 3 with the possibility of a lack of particle size uniformity in the formula. Therefore, the selected formula of microemulsion is $1: 3$.

The penetration test results of the Franz diffusion method

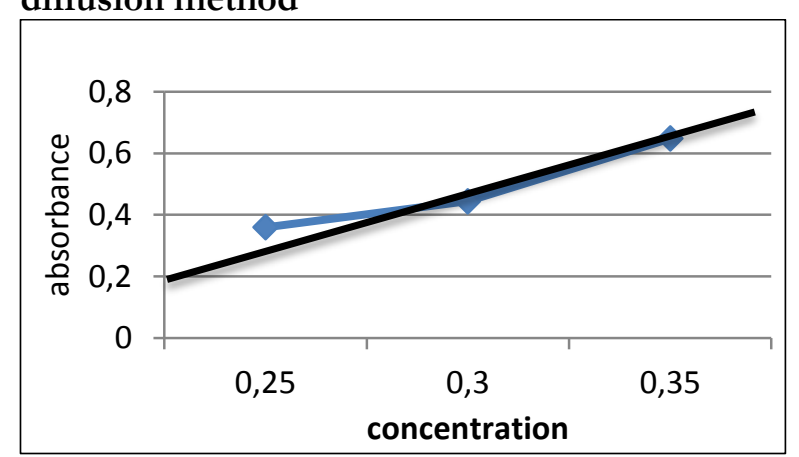

Figure 2. Standard curve

Digram 2 shows the comparison standard curve equation before Franz diffusion testing. After making the standard curve equation the penetration power test of the cream of red yeast rice extract and cream of microemulsion with receptor medium was filled with $15 \mathrm{ml}$ of phosphate buffer $\mathrm{pH} 7.4$ as much as $15 \mathrm{ml}$. The use of phosphate buffer $\mathrm{pH} 7.4$ because this 
solution describes the physiological fluid of the body. The temperature used during the penetration test is $37^{\circ} \mathrm{C}$ where this temperature is the normal temperature of the human body. The temperature must be kept constant because temperature changes will affect the penetration of the active substance from the cream preparation.

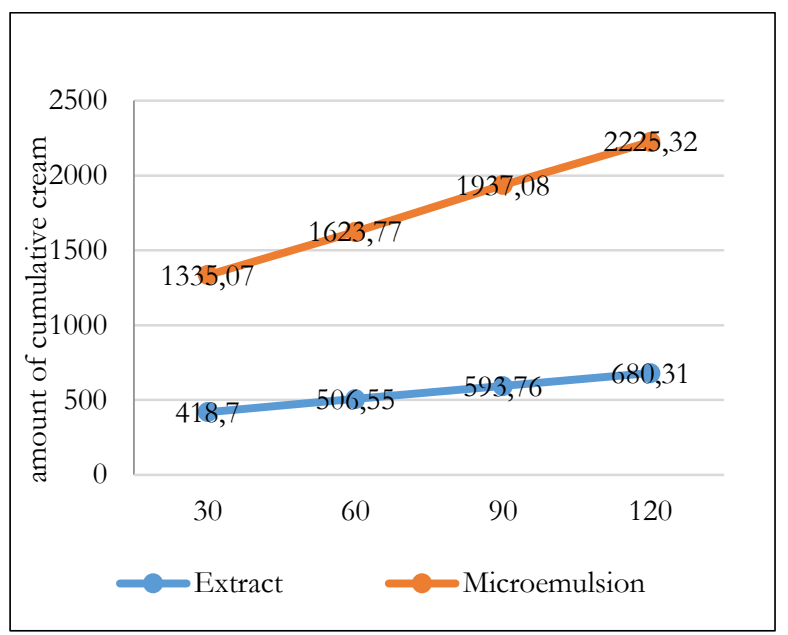

Figure 3.Difference in the amount of cumulative penetrated cream

The study of skin penetration in vitro is related to the assessment of bioavailability of active substances in the skin by measuring the speed and number of components that penetrate the skin and the number of components retained in the skin (Witt \& Bucks 2003).

The results showed that the cumulative amount of microemulsion cream was greater than red yeast rice extract cream. This happens because the microemulsion cream theoretically has a globul interface voltage that is smaller than the extract cream which was not emulsified first and the microemulsion cream has high absorption and permeation (Talegaonkar et al. 2008).

The cumulative amount of penetrated cream (Q) microemulsion cream is greater than that of red yeast rice cream because microemulsion cream can increase the absorption of drug molecules topically by increasing the solubility of the active substance and modifying the partition coefficient. Therefore, the purpose of making microemulsion cream is to increase the effect by increasing the bioavailability of red yeast rice extract can be achieved.

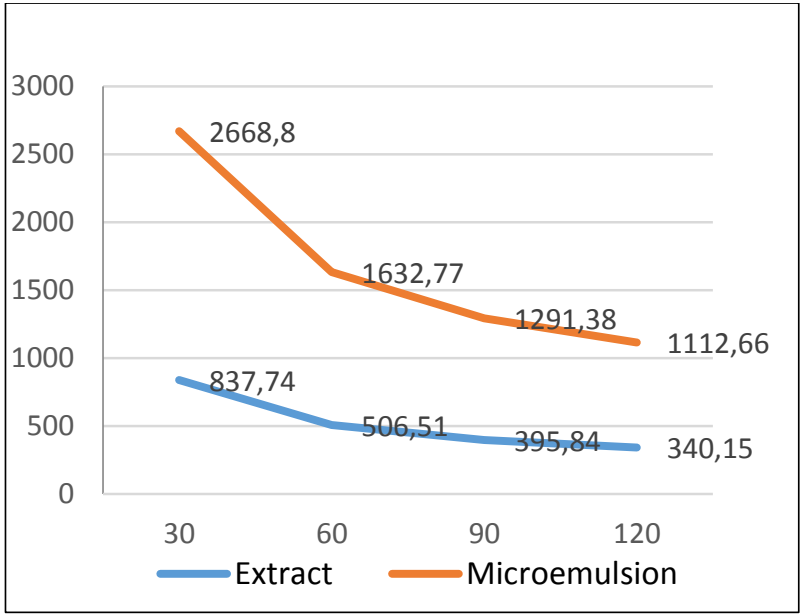

Figure 4.Penetrated cream speed flux

The result of penetrated cream flux per unit time shows the penetration rate of each cream has decreased every sampling time. The peak time of penetrated cream speed (flux) is 30 minutes which indicates that the cream preparation has been absorbed in 30 minutes. Penetration speed is decreasing but the levels of penetrated substances in it continue to increase which indicates that the bioavailability of the extract is increasing.

Figure 4 shows the microemulsion cream has flux or penetrated time speed greater than the extract cream, this occurs because the microemulsion has a structure that allows the mobility of the active substance in the extract that is high in the carrier so that it can increase the diffusion of the active substance through the skin surface so that the flux preparations can increase (Isik SO et al. 2006).

Repeated ANOVA test showed that there was a significant difference $(\mathrm{P}<0.05)$ at each time the penetrated cream and the speed of the cream penetrated both red yeast rice extract cream and microemulsion cream. This means that there are significant differences at each sampling time. Pairwise comparisons table shows the relationship between the time of the first sampling to the last sampling.

The test results showed a significant value $(\mathrm{P}<0.05)$ means that there is a difference in the amount of cumulative cream and penetrated cream speed at each sampling time, where the value of the amount of cumulative cream penetrated increases and the penetration speed decreases each time sampling. Independent ttest on concentration speed (flux) showed a significant difference $(\mathrm{P}<0.05)$ between the red yeast rice extract cream with microemulsion cream at each sampling time. 


\section{The results of safety test}

Safety tests were performed to determine the degree of irritation in vivo in the three rabbits using the Draize method. Irritation is a symptom of inflammation that occurs in the skin or mucous membranes immediately after prolonged or repeated treatment using chemicals or other ingredients. Irritation test is carried out on cosmetic preparations before being sold to the general public. An irritation test is done to prevent the occurrence of side effects on the skin.

Observations for irritation tests were carried out at $0,24,48$ and 72 hours after the test preparation was given by observing the skin reactions that occurred with 2 observation parameters i.e. erythema level (redness reaction) and edema level (swelling) that arises. Observations at 24, 48 and 72 hours after the bandage was released aiming to determine the possibility of delayed irritation reactions (Sulaksmono 2001). Then the results of these observations are scored 0 to 4 according to their severity. The level of irritation is calculated based on the calculation of the observation score.

Table 4. Results of Primary irritation test

\begin{tabular}{lcl}
\hline \multicolumn{1}{c}{ Sample } & PII & \multicolumn{1}{c}{ Results } \\
\hline Control cream & 1 & very little irritation \\
Red yeast rice cream & 3 & slightly irritation \\
Microemulsion & 1,67 & very little irritation \\
\hline
\end{tabular}

Explanation :PII (primary irritation index)

From the results of the observation on the primary irritation test, the negative control cream is very little irritation with the primary irritation index 1, red yeast rice extract cream is slightly irritating and the microemulsion cream is very little irritating. This result is not considered dangerous because basically the sensitivity of rabbit skin is slightly different from human skin. An ocular irritation test is performed to ensure that the preparation does not irritate when it enters the eye. Observations were made for 3 days by seeing the occurrence of irritation in the iris, cornea, conjunctiva, and chemosis of the rabbit's eyes. Observation data can be seen in the table below.

Table 5. Resultas of ocular irritation test

\begin{tabular}{lcl}
\hline Sample & OII & Resultas \\
\hline Control cream & 0 & no irritation \\
Red yeast rice cream & 0 & no irritation \\
Microemulsion & 0 & no irritation
\end{tabular}

Explanation : OII (ocular irritation index)
From the observations it was seen that all cream preparations did not irritate rabbit eyes with zero ocular irritation index.

\section{Conclusion}

First, red yeast rice extract has an $\mathrm{IC}_{50}$ value of $2.60 \mathrm{ppm}<50 \mathrm{ppm}$ which indicates that extract has strong antioxidant activity.

Second, microemulsion cream have greater penetration power compared to red yeast rice extract cream seen from the value $(\mathrm{Q})$ of the cumulative amount of penetrated cream and cream penetration rate (flux)

Third, red yeast rice extract cream and red yeast rice extract microemulsion had PII (primary irritation index) of 3 and $1.67<8.00$ (slightly irritating cream) and OII (ocular irritation index) of $0.00<8.00$ (no irritation) so that the microemulsion cream of red yeast rice extract is safe to use as a cosmetic product.

\section{References}

Anonim. 2014. Farmakope Indonesia Edisi V. Jakarta: Departemen Kesehatan Republik Indonesia.

Andriani Martina. 2009. The Effect Of Rice Variety To Antimicrobia Activity Of Red Mould Rice By Monascus purpureus. Caraka tani XXIV (1).

Chairote E, Chairote G, Lumyong, Saisamorn. 2009. Red Yeast Rice Prepared from Thai Glutinous Rice and the Antioxidant Activities. Chiang Mai J. Sci 36(1):42-49.

Dewiastuti M, Hasanah I.F. 2016. Pengaruh Faktor-Faktor Risiko Penuaan Dini di kulit Pada Remaja Wanita Usia 18-21 Tahun. Jurnal Profesi Medika. Vol.10 (1).

Dizaj SM. 2013. Preparation and study of vitamin A palmitate microemulsion drug delivery system and investigation of cosurfactant effect. Journal of Nanostructure in Chemistry. 3(1).

Grampurohit N, Ravikumar P, dan Mallya R. 2011. Mikroemulsions For Topical. [Review]. Indian Journal of Pharmacentical Education and Reserch. 45 (100-107).

Isik SO et al. 2006. Transdermal Delivery of Diclofenac Sodium Throught Rat Skin 
From Various Formulation. AAPS PharmSciTech. Vol 7 (4). Hlm 88.

Jenie BSL, Ridawati, Winiati PR. 1994. Produksi Angkak oleh Monascus purpureus dalam Medium Limbah Cair Tapioka, Ampas Tapioka dan Ampas Tahu. Buletin Teknologi dan Industri Pangan 5(3): 60-64.

Molyneux P. 2004. The Use of the Stable Free Radical Diphenylpicryl-hydrazyl (DPPH) for Estimating Antioxidant Activity. Songklanakarin Journal of Science and Technology. 26 (211-219).

Pratimasari D. 2009. Uji Aktivitas Penangkap Radikal Buah Carica papaya L. Dengan Metode DPPH dan Penetapan Kadar Fenolik Serta Flavonoid Totalnya. [Skripsi]. Surakarta: Fakultas Farmasi, Universitas Muhammadiyah Surakarta.

Shahidi F, Ambigaipalan P. 2015. Phenolics and polyphenolics in foods, beverages and spices: Antioxidant activity and health effects-A review. J Funct. Foods. 18: 820897.
Shalviri A et al. 2011. Low-surfactant microemulsions for enhanced topical delivery of poorly soluble drugs. Journal of Pharmacy \& Pharmacentical Sciences. 14(3), $315-324$

Sulaksmono. 2001. Keuntungan Dan Kerugian Patch Test (Uji Tempel) Dalam Upaya Menegakkan Diagnosa Penyakit Kulit Akibat Kerja (Occupational Dermatosis). Surabaya : Universitas Airlangga.

Talegaonkar et al. 2008. Microemulsions: A Novel Approach to Enhanced Drug Delivery. Recent Patents on Drug Delivery \& Formulation. (2).238-257.

Wanti Surtika. 2008. Pengaruh berbagai jenis beras terhadap aktivitas antioksidan pada angkak oleh Monascus purpureus [Skripsi]. Surakarta: Fakultas Pertanian, Universitas Sebelas Maret.

Witt K, Bucks D. 2003. Studying In Vitro Skin Penetratrion and Drug Release to Optimize Dermatological Formulations. Pharmaceutical Technology. New York: Anvanstar 